\title{
COWS AND GOATS AS SENTINELS FOR ENVIRONMENTAL LEAD (Pb) BURDEN IN ZARIA, NIGERIA
}

\author{
Udiba Udiba Ugumanim', Ibrahim Moses", Chindo Hilda Jonah", Zakariyya Ahmad', Dawaki Saleh Idris', \\ Abdullahi Mahmood', Agboun Temeweidoubra Deboral \\ I - National Research Institute for Chemical Technology, Zaria, Nigeria \\ II - Ahmadu Bello University, Zaria, Nigeria
}

\section{ABSTRACT}

Blood lead levels (BLLs) is considered as a good indicator of current body burden of the toxic metal. Assessment of BLLs of white Fulani cattle (Bos primigenius indicus)and red Sokoto goats (Capra aegagrus hircus) grazed freely on open pastures in Zaria was carried out by Atomic Absorption Spectrophotometry using Shimadzu Atomic Absorption Spectrophotometer (model AA-6800, Japan) after wet digestion to evaluate the potential effects of the metal on the animals, the toxicological implication of consuming this major source of animal protein by humans and most importantly as an indirect measure of the lead pollution status of Zaria ecological geochemical environment. The blood lead levels of Bos primigenius indicus ranged from a minimum of $0.62 \mathrm{mg} / \mathrm{l}$ to a maximum of $2.28 \mathrm{mg} / \mathrm{l}$ with a mean value of $1.36 \pm 0.48 \mathrm{mg} / \mathrm{l}$. On the other hand, blood lead levels of Capra aegagrus hircus ranged between 0.26 $\mathrm{mg} / \mathrm{l}$ and $1.56 \mathrm{mg} / \mathrm{l}$ with a mean value of $0.89 \pm 0.43 \mathrm{mg} / \mathrm{l}$. The BLLs of both cows and goats were found to exceed the allowable limit for the elements in blood of food animals indicating that cows and goats grazed freely on open pastures in Zaria metropolis are not safe for human consumption. Routine monitoring of the heavy metal in plant and animal products is therefore recommended to safeguard human health. Most importantly, the study indicates the presence of elevated levels of environmental lead in Zaria ecological geochemical environment.

\section{UDC \& KEYWORDS}

- UDC: 591.5 " BLLS " ANIMALS " BODY BURDEN TOXICOLOGICAL IMPLICATIONS $\approx$ POLLUTION

\section{INTRODUCTION}

The science of inferring the environmental conditions of a place by examining the organism that live there, is fast gaining acceptance world over as an indirect method for assessing human exposure to extraneous substances. The technique (biomonitoring) has become a more useful tool in recent years as the result of advancements in the capability to measure "more and more minute amounts of chemicals" in organisms to which they are exposed (Karim, 2004). It is a reliable tool that may be used to assess the levels of any chemicals, natural or synthetic, that are present or that have been present in the environment. Heavy metals are simply outstanding among naturally occurring chemicals that have been the subject of biomonitoring (Karim, 2004). This technique is best at detecting heavy metals that are not rapidly broken down and/or excreted. It is perceived not only as an accurate method, but also as a comprehensive, flexible, time and money saving package for environmental health \& safety compliance and management (Karim, 2004). It can also act as an "early warning" of harmful conditions and/or as "fingerprint" of local environmental pollution. The term "body burden of lead" refers to the total amount of the toxic heavy metal that is present in the human body at a given point in time. This

' udiba.udiba@yahoo.com dangerous substance often gets into the human body through various routes. We may inhale them, swallow them in contaminated food or water, or in some cases, absorb them through our skin (Karim, 2004).

Pollution caused by anthropogenic lead has its origin mostly from activities such as leaded gasoline, incineration of waste, burning of coal, mining, smelting and industrial uses. In adults, lead poisoning often affects the central and peripheral nervous systems as well as liver, kidney and blood pressure (Needleman, 2004). Children are more easily affected by lead poisoning than adult, with their exposure to the toxic metal causing, irreversible damage to the brain. Lead poisoning which is also known as plumbism is a medical condition caused by increased level of the metal in the body. Staudinger and Ruth, (1998) stated that "plumbism was among the first known and widely studied environmental hazards. Contaminated soil, water, air, consumer products and food are recognized as some of the common routes of exposure. Occupational exposure has been recognized as one of the commonest causes of lead poisoning in adults. In the United States for instance, more than 3 million workers are said to be exposed to the toxic metal in the workplace (Staudinger \& Ruth, 1998). Several deaths linked to lead poisoning were reported in Zamfara state, North Eastern Nigeria in 2010. World Health Organization (WHO) and the Zamfara State Ministry of Health $(\mathrm{ZMoH})$ confirmed the report and estimated that over 10,000 people have been affected. The source of the crisis was traced to environmental exposure to lead resulting from artisanal gold mining and associated processing of the lead-rich ore (Joint UNEP/OCHA, 2010). The bad news is that between 2010 and 2013 well over 700 children have been reported death in what is described as the worst lead poisoning crisis world over in 40 years (Kabara, 2014). A similar crisis is currently unfolding in Niger State, North central Nigeria where over twenty eight children have so far been reported death in May 2015 (Sun, 2015).

The earliest documented accounts of lead toxicity are found in the Egyptian papyrus scrolls. According to these records, compounds of the toxic heavy metal were mostly used for homicidal purposes around 2000 BC (Sven, 2000). In the Roman's Empire, the metal and its compounds were extensively used for glazing, pottery, cooking utensils and piping. Lead pots were also used to boil and condense grape juice for the preservation and sweetening of the wine. Lead poisoning from all the sources mention above must have been common in the ancient Rome (Sven, 2000; Gilbert \& Weiss, 2006).

Acute $\mathrm{Pb}$ poisoning is not common in most countries of the world in recent times due to the reduction of the metal in products and workplace, and the ban on leaded gasoline. However, "low level exposure is still common" in many countries. It is interesting to note that, though $\mathrm{Pb}$ poisoning is recorded as one of the oldest known environmental hazards, it was not until the latter half of the $20^{\text {th }}$ century that the modern understanding of the small amount necessary 
to cause harm began to come (WHO, 1984). It is also interesting to note that, till date, the level that must be reached for psychological or physiological effect to begin has not been discovered (Joint UNEP/OCHA, 2010). There is therefore "no known amount" of the toxic metal "that is too small to cause harm" to the human body.

In Nigeria as well as several other countries, meat and milk from cattle, goats and sheep are the most common sources of animal protein. The need to assess the level of lead in these animals is absolutely necessary for the protection of public health. Since body fluids are considered as a good indicator of current body burden of metals, assessment of blood lead levels of these animals specially in Zaria and most other cities in Northern Nigeria where grazing by privately owned domestic livestock is the most extensive economic use of the public lands, provides significant information about the lead pollution status of the environment. Lead poisoning and pollution in Zamfara and Niger States in Northern Nigeria has currently assumed the centre stage of discuss as one of the world worst environmental hazards. This study was thus designed to assess the lead pollution status of Zaria metropolis using Bos primigenius indicus and Capra aegagrus hircus grazed predominantly around Zaria. The implications of consuming these animals for public health are thoroughly examined.

\section{Methodology}

Study Location

Zaria is located within latitude $1103 \mathrm{~N}$ and $11015^{\circ} \mathrm{N}$ of the Equator and longitude $07033^{\circ} \mathrm{E}$ and $07045^{\circ} \mathrm{E}$ of the Greenwich Meridian, $128 \mathrm{~km}$ Southeast of Kano and $64 \mathrm{~km}$ North-east of Kaduna City. River Galma is the main drainage channel in Zaria since other rivers and streams discharge into it. It is located at the South-eastern part of Zaria and originates from Jos Plateau in the South-western area of the Shetu Hills, which is some $350 \mathrm{~km}$ away from Zaria. Galma Dam is located on the Galma River, at a distance of about $10 \mathrm{~km}$ Northeast of Zaria town. (Abdulrafiu, 1997). The other river that drains the ancient city of Zaria is the Kubanni River which originates from the precincts of the Ahmad Bello University (ABU) Main Campus, Zaria, as a trench in an undulating agricultural land and is fed by a number of tributaries (Uzairu et al., 2009). Kubanni River drains the northwest zone of the city of Zaria and receives effluents mainly from domestic activity and runoff from intense cropping located in the adjoining land. The ABU dam is on the river (Uzairu et al., 2009). The geology of the study area is basement of complex rock composed mainly of fine grain gneisses and migmatite with some coarse-grained granite outcrop in few places. The gneisses are moderately to weakly floated, primarily made up of quartz and oligoclase, depth of weathering is regular but thorough, the depth ranges from 10 meters to deep pocket, occasionally extending to about 60 meter. Due to poor conservation and land use practice like extensive vegetation clearance for agricultural and urban development purposes intensive grazing, livestock tracks and human foot paths criss-crossing the area overland flow, rilling and gullying have become the dominant mode of rain water disposal from the landscape (Ologe, 1971; Bello, 1973; and Iguisi, 1996). The catchment area lies in the natural vegetation zone known as the Northern Guinea Savannah. Unfortunately, this characteristic vegetation cover is hardly preserved due to urbanization and other anthropogenic activities and poor management practices, like cultivation, intensive grazing, fuel wood harvesting and annual bush burning (Ologe, 1971). Rainfed agriculture and irrigation are the two major forms of agricultural activities practice in the Galma catchment. The rainfed agriculture is a rainy season activity which takes place on the upland fields.

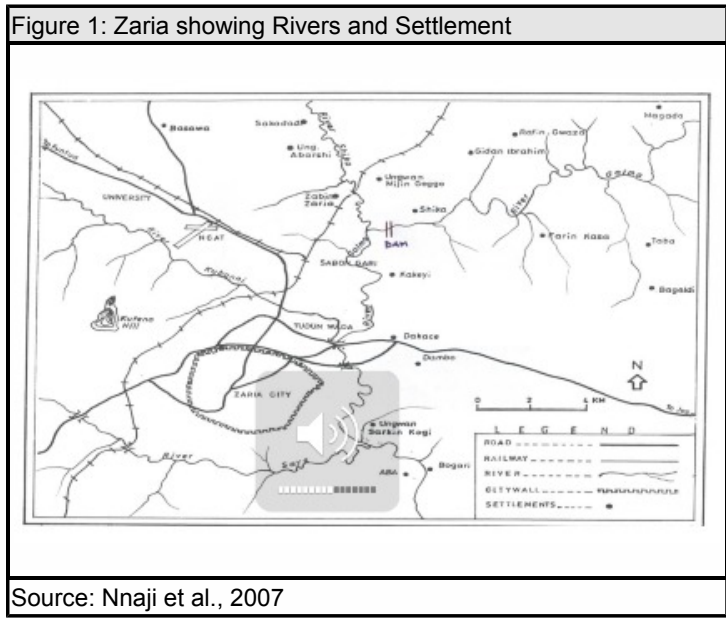

Sample Collection

Measurement of $\mathrm{Pb}$ levels in animal blood was carried out following methods by Ogabiela et al (2011). Blood samples were collected from twenty (20) randomly sampled white Fulani cattle (Bos primigenius indicus) and twenty (20) randomly sampled red Sokoto goats (Capra aegagrus hircus) grazed extensively on natural pastures and fed with water around Zaria. Blood samples were also collected from white Fulani cattle (Bos primigenius indicus) and red Sokoto goats (Capra aegagrus hircus) feed on cultivated pastures/concentrates at National Animal Production Research Institute, Zaria. The latter was used as control Blood collection was carried out by venipuncture using sterilized disposable syringe and needles. About $3 \mathrm{ml}$ of blood was taken into sterilized polypropylene tubes containing ethylenediaminetetraacetic acid (EDTA) as anticoagulant.

Preservation and preparation of animal blood samples

The polypropylene tubes containing blood samples were preserved in ice-chest and transported to the Environmental Laboratory, National Research Institute for Chemical Technology (NARICT), Zaria, Nigeria at temperature of $<4^{\circ} \mathrm{C}$ for preparation and analysis.

$1 \mathrm{ml}$ of the blood sample was pipetted into a clean test tube using $1 \mathrm{ml}$ micro pipette and digested with $10 \mathrm{ml}$ concentrated nitric acid and concentrated perchloric acids in the ratio of $3: 1$ on a hot plate at $60^{\circ} \mathrm{C}$. The digest was filtered warm using Whatman filter paper No. 1 into $50 \mathrm{ml}$ volumetric flask and the filtrate made upto the mark with distilled deionized water.

Sample analysis

Lead concentrations in the digests were determined by Atomic Absorption Spectrophotometry, using Shimadzu Atomic Absorption Spectrophotometer (model AA-6800, Japan) equipped with Zeeman background correction and graphite furnace at National Research Institute for Chemical Technology (NARICT), Zaria, Nigeria. The calibration curve was prepared by running different concentrations of the standard solution (lead II nitratein nitric acid). The instrument was then set to zero by running the respective reagent blanks and lead $(\mathrm{Pb})$ concentration determined at a wavelength of $283.3 \mathrm{~nm}$. Average values of three replicates were taken for each 
determination. Data obtained were subjected to statistical analysis.

Analytical quality assurance

In order to check the reliability of the analytical method employed for lead $(\mathrm{Pb})$ determination, one blank and combine standards were run with every batch of 20 samples to detect background contamination and monitor consistency between batches. The result of the analysis was validated by digesting and analyzing Standard Reference Materials, animal blood coded IAEA-A-13 following the same procedure. The standard reference material was obtained from Internal Atomic Energy Agency, analytical quality control unit, Vienna international center, 1400 Vienna Australia. The analyzed values and the certified reference values of the elements determined were compared to ascertain the reliability of the analytical method employed. All the reagents used - $\mathrm{HNO}_{3}$ (Riedel-deHaen, Germany), and $\mathrm{HClO}_{4}$ (British Drug House Chemicals Limited, England) were all of analytical grade.

Statistical analysis

Independent t-test was used to compare blood $\mathrm{Pb}$ levels of white Fulani cattle (Bos primigenius indicus) grazed freely on open fields in Zaria and the blood lead levels of Bos primigenius indicus from NAPRI (control). The blood lead levels of red Sokoto goats (Capra aegagrus hircus) grazed freely on open pastures around Zaria and blood lead levels of Capra aegagrus hircus from NAPRI (control) were also compared using independent t-test. Probabilities less than $0.05(p<0.05)$ were considered statistically significant. SPSS software 17.00 for windows was used for all statistical analysis

\section{Results}

To evaluate the accuracy and precision of the analytical procedure employed, Standard reference materials of animal blood coded IAEA-A-13 was analyzed in like manner to our samples. The analyzed values and the certified reference values of the elements determined were very close suggesting the reliability of the method employed (Table 1).

Results obtained from the determination of blood lead levels of White Fulani cattle (Bos primigenius indicus) and Red sokoto (Capra aegagrus hircus) grazed freely around Zaria and National Animal Production Research Institute are presented in Table 2. The comparison of the blood lead levels of White Fulani cattle (Bos primigenius indicus) and Red sokoto (Capra aegagrus hircus) grazed freely around Zaria and those fed on cultivated pastures/ concentrates at National Animal Production Research Institute is shown in Figure 2.

Table 1: Results of analysis of reference material (animal blood IAEA-A-13) compared to the certified reference value ( $\mathrm{mg} / \mathrm{kg})$

\begin{tabular}{|l|l|l|l|l|l|}
\hline $\begin{array}{l}\text { Element } \\
(\mathrm{mg} / \mathrm{kg})\end{array}$ & $\mathrm{Pb}$ & $\mathrm{Ni}$ & $\mathrm{Cu}$ & $\mathrm{Fe}$ & $\mathrm{Zn}$ \\
\hline A Value & 0.2 & 1.2 & 4.45 & 2399 & 14.2 \\
\hline R value & 0.18 & 1 & 4.3 & 2400 & 13 \\
\hline A value = Analyzed value, $R$ value = Reference value \\
\hline Source: Authors
\end{tabular}

www.journals.cz

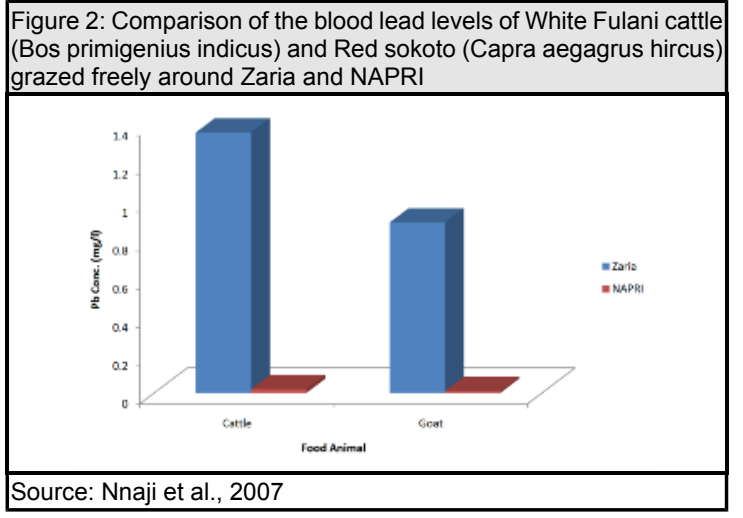

Table 2: Blood lead levels of White Fulani cattle (Boss primingenius indicus) and Red sokoto goats (Capra aegagrus hircus), Basawa Village Zaria and NAPRI

\begin{tabular}{|c|c|c|c|c|}
\hline $\mathrm{S} / \mathrm{N}$ & $\begin{array}{c}\text { Zaria Cattle } \\
\mathrm{Pb}(\mathrm{mg} / \mathrm{l})\end{array}$ & $\begin{array}{l}\text { Zaria Goats } \\
\text { Lead }(\mathrm{mg} / \mathrm{l})\end{array}$ & \begin{tabular}{|c|} 
NAPRI Cattle \\
$\mathrm{Pb}(\mathrm{mg} / \mathrm{l})$
\end{tabular} & $\begin{array}{c}\text { NAPRI Goat } \\
\mathrm{Pb}(\mathrm{mg} / \mathrm{l})\end{array}$ \\
\hline 1 & 1.18 & 1.1 & 0.01 & 0.01 \\
\hline 2 & 1.16 & 1.18 & 0.04 & 0.02 \\
\hline 3 & 1.24 & 1.12 & 0.03 & 0.02 \\
\hline 4 & 1.22 & 0.96 & 0.02 & 0.01 \\
\hline 5 & 1.26 & 0.94 & 0.01 & 0.01 \\
\hline 6 & 1.32 & 1.16 & 0.03 & 0.01 \\
\hline 7 & 1.27 & 0.98 & 0 & 0 \\
\hline 8 & 1.31 & 1 & 0 & 0 \\
\hline 9 & 2.27 & 0.27 & 0 & 0 \\
\hline 10 & 2.26 & 0.26 & 0 & 0 \\
\hline 11 & 2.28 & 0.28 & 0 & \\
\hline 12 & 0.63 & 1.56 & 0 & 0 \\
\hline 13 & 0.62 & 1.54 & 0 & 0 \\
\hline 14 & 0.64 & 1.55 & 0 & 0 \\
\hline 15 & 1.56 & 0.38 & 0 & \\
\hline 16 & 1.59 & 0.4 & 0 & 0 \\
\hline 17 & 1.62 & 0.39 & 0 & 0 \\
\hline 18 & 1.28 & 0.9 & 0 & 0 \\
\hline 19 & 1.25 & 0.92 & 0 & 0 \\
\hline 20 & 1.31 & 0.91 & 0 & 0 \\
\hline Mean \pm SD & $1.36 \pm 0.48$ & $0.89 \pm 0.43$ & $0.02 \pm 0.01$ & $0.01 \pm 0.01$ \\
\hline Range & $0.62-2.28$ & $0.26-1.56$ & 0.01-0.04 & $0.01-0.02$ \\
\hline Standards & ${ }^{*} 0.02$ & ${ }^{*} 0.02$ & ${ }^{\star} 0.02$ & ${ }^{*} 0.02$ \\
\hline \multicolumn{5}{|c|}{ Source: Authors } \\
\hline
\end{tabular}

Table 2 and Figure 2 show that the blood lead levels of white Fulani cattle (Bos primigenius indicus) grazed freely on open fields in Zaria ranged from a minimum of $0.62 \mathrm{mg} / \mathrm{l}$ to a maximum of $2.28 \mathrm{mg} / \mathrm{l}$ with a mean value of $1.36 \pm 0.48$ $\mathrm{mg} / \mathrm{l}$ and the blood lead levels of Bos primigenius indicus from NAPRI (control) ranged from $0.01 \mathrm{mg} / \mathrm{l}$ to $0.04 \mathrm{mg} / \mathrm{l}$ with a mean value of $0.02 \pm 0.01 \mathrm{mg} / \mathrm{l}$. Statistical analysis revealed that the difference in blood lead levels of Bos primigenius indicus from the different sampling locations in the study was found to be statistically significant (ANOVA, $p<0.05$ ), with the blood lead levels of Bos primigenius indicus grazed freely around Zaria being significantly $(p<0.05)$ higher than the BLLs of Bos primigenius indicus from NAPRI. On the other hand, blood lead levels of red Sokoto goats (Capra aegagrus hircus) grazed freely on open pastures around Zaria ranged between $0.26 \mathrm{mg} / \mathrm{l}$ and $1.56 \mathrm{mg} / \mathrm{l}$ with a mean value of $0.89 \pm 0.43 \mathrm{mg} / \mathrm{l}$ and the blood lead levels of Capra aegagrus hircus from NAPRI ranged from $0.01 \mathrm{mg} / \mathrm{l}$ to $0.02 \mathrm{mg} / \mathrm{l}$ with a mean value of $0.01 \pm 0.01 \mathrm{mg} / \mathrm{l}$. The difference in blood lead levels of Capra aegagrus hircus from the two sampling locations was found to be statistically significant (ANOVA, $p<0.05$ ) with the 
blood lead levels of Capra aegagrus hircus grazed freely around Zaria being significantly higher than the BLLs of Capra aegagrus hircus grazed on cultivated pastures and concentrates from NAPRI.

\section{Discussion}

Farm animals reared freely on pasture are the indicators of environmental pollution. Respiration of polluted air, ingestion of contaminated feed/water and skin contacts are the major exposure routes through which metals gain entrance into and bioaccumulates increasingly in organs and tissues of these animals. Toxicity depends on animal species, and dose, and length of their action upon the animal (Abou-Donia, 2008). Blood is a good indicator of current lead exposure and is the most frequently used sample for monitoring lead status in food animals (Rumbeiha et al., 2001). The elevated blood lead levels of cattle and goats grazed freely on natural pastures round Zaria, Kaduna state compared to those reared intensively, grazed on cultivated pastures and concentrates at National Animal Production Research Institute (Control), Zaria (Figure 2) may be attributed to elevated level of the toxic metal in the environment in which they live and with which they interact. As shown in Table 2, the mean blood lead levels of cattle $(1.36 \pm 0.48 \mathrm{mg} / \mathrm{l})$ and goats $(0.89 \pm 0.43 \mathrm{mg} / \mathrm{l})$ grazed freely on open pastures around Zaria were found to be higher than the allowable limit $(0.02 \mathrm{ppm})$ for lead in blood of food animals (Ogabiela et al., 2011). Animals grazed freely in Zaria may have been exposed to lead from industrial discharges, lead based agrochemicals, and automobile exhaust fumes. The study therefore point to the fact that there is an elevated levels of bioavailable fraction of the toxic heavy metal in the study area. The blood lead levels observed in this study could be said to indicate health risk to the animals under study and consequently to humans who are higher up in the food chain. The average blood lead level of cattle and goats from NAPRI (control) were found to be within the acceptable limits. Blood lead levels in excess of $0.35 \mathrm{ppm}$ are normally regarded as diagnostic of lead intoxication and $0.40 \mathrm{mg} / \mathrm{l}$ is considered terminal for livestock (Oluokun, 2007). It has been reported that lead level below $10 \mu \mathrm{g} / \mathrm{dL}$ of blood is linked with kidney failure, immunosuppression, suppression of hematological system, impairment of neurological development etc (UNEP, 2007). Elevated levels of certain metals in animals interfere with the absorption of other metals. High concentrations of lead for instance blocks the absorption of potassium, Calcium, Magnesium, Manganese, Zinc, Copper, and iron which are essential elements. This certainly would affect tissue metal concentrations as well as a good number of physiological processes (Kafeel et al., 2013). The long term storage site for lead in animals is the bones. Pregnant animals present a very special case when it comes to led toxicity. "At pregnancy/parturition there is increase in calcium requirements, leading to mobilization of calcium from the bones. Concentration of lead in blood increases at parturition probably due to mobilization of lead from the bone long with calcium" (Kafeel et al., 2013). Lead with a similar valence as calcium actually has greater affinity for the calcium binding sites. This may account for the elevated BLLs recorded for three cows at National Animal Production Research Institute as investigation revealed that the three cows were all lactating. Lead based agrochemicals used for pest control at the cultivated pastures, feed concentrates and water feed to the animals are also possible sources of exposure. Blood lead levels recorded in this study for cattle and goats were higher than most recorded literature values. A mean value of $349 \pm 82.0 \mu \mathrm{g} / \mathrm{L}$ was reported for lactating cows reared around lead slag dumpsites in Ibadon, Nigeria (Ogundiran et al., 2012). A range of 0.001-1.37 (0.54 \pm 0.42 pmm) and 0.50-0.99 (0.79 $\pm 0.17 \mathrm{ppm})$ was reported for cows grazed around Challawa Industrial Estate, Kano and Zango, Zaria, Kaduna state - Nigeria (Ogabiela et al., 2011). A range of $0.21-10.6 \mathrm{mg} / \mathrm{kg}$ was reported for cows slaughtered at Awka abattoir, Nigeria (Nwude et al., 2010) and $0.0004-0.007 \mathrm{mg} / \mathrm{L}$ for lactating cows reared at suburb of Sarghoda, Pakistan (Khan et al., 2012). The values $0.403 \mu \mathrm{g} / \mathrm{l}$ and $0.402 \mu \mathrm{g} / \mathrm{l}$ were reported for calves from industrialized and rural area of Northern Spain (Miranda et al., 2005). Blood lead levels of goats in this study was also found to be higher than recorded values from previous studies. Mean blood lead levels of $0.511+0.12 \mathrm{ppm}$ and $0.085+0.01 \mathrm{ppm}$ were reported for goats raised in cement kiln dust polluted and non-polluted areas of Shagamu, Nigeria (Oluokun et al., 2007). Brownet al., (2009) recorded a slightly higher mean value of $1.02 \pm 0.10 \mu \mathrm{g} / \mathrm{dl}$ for goats in the Caribbean basin islands, Jamaica.

\section{CONCLUSION}

Assessment of blood lead levels of food animals in cities where grazing by privately owned domestic livestock is the most extensive economic use of the public lands provides significant information about the lead pollution status of the environment. Food animals(cows and goats) roam and graze freely on open pastures in Zaria and as such have access to industrial discharges, waste dump sites where potentials for lead exposure is great as well as exhaust fumes and dust deposits on pastures grasses. The blood lead levels of cows and goats grazed freely on open pastures in Zaria was found to exceed the allowable limit for the elements in blood of food animals thus pointing to the fact that cows and goats grazed freely on open pastures in Zaria metropolis are not safe for human consumption. Routine monitoring of the heavy metal in plant and animal products is therefore absolutely necessary to safeguard human health. Most importantly, the study indicates the presence of elevated levels of environmental lead in Zaria ecological geochemical environment.

\section{Acknowledgement}

The research team wishes to express her profound gratitude to National Research Institute for Chemical Technology (NARICT), Zaria-Nigeria, for making their environment laboratory available for this research work.

\section{REFERENCES}

Abdulrafiu, B.G. (1977). Land Use Changes Associated with the New Galma dam in Zaria, Unpublished B.Sc. Dissertation, Geography Department, Ahmadu Bello University, Zaria, Nigeria.

Abou-Donia, M.A. (2008). Lead Concentrations in Different Animals Muscles and Consumable Organs at Specific Localities in Cairo. Global Veterinaria, 2 (5), 280-284.

Bello, A.L. (1973). The Morphology of an Erosional Scarp, South of Ahmadu Bello University, Zaria. Unpublished B.A Dissertation, Department of Geography, ABU, Zaria.

Brown, T. J., Hetherington, L.,Hannis, S.,Bide, T.,Benham, A J.,Idoine, N. and Lusty, P. (2009). World Mineral Production 20032007. British Geological Survey, 2009. Retrieved January 20, 2012, from, http://nora.nerc.ac.uk/6251/

Gilbert, S. G. \& Weiss, B (2006). A Rationale for Lowering the Blood Lead Action Level from 10 to $2 \mu \mathrm{g} / \mathrm{dL} "$. Neurotoxicology27 (5), 693-701.

Iguisi, E.O. and Falade, A.M. (2009).Fluxes in Suspended Sediment Concentration and Total Dissolved Solids Upstream of the Galma Dam, Zaria, Nigeria.A paper presented at the $21^{\text {st }}$ Annual Conference of the Nigeria Association of Hydro Geologists (NAH). 
Joint UNEP/OCHA Environment Unit, (2010). Lead pollution and poisoning crisis, environmental emergency response mission, Zamfara State, Nigeria. Switzerland: Joint UNEP/OCHA Environment Unit.

Kabara A. A. (2014). Zamfara lead poison update: 735 Child Deaths Recorded, 1450 on Treatment-MSF. Leadership Online News Paper, August $3^{\text {rd }} 2014$.

Kafeel, A., Zafar, I K., Yousuf, R., Muhammad, S., Muhammad, K M., Rab, N. and Muneeba S, F M, (2013). Nickel, lead and manganese content of forages irrigated with different sewage water treatments: A case study of a semiarid region (Sargodha) in Pakistan. Agricultural Sciences, 4(4), 180-184.

Kamrin M. A. (2004). Biomonitoring Basics, retrieved May 28, 2012 from www.biomonitoring.org.

Khan, Z. I., Ahmad, K., Sher, M., Hayat, Z., Hussain, A.,Seidavi, A. \& Rizwan, Y.(2012). A Study on Soil, Forage and Plasma Lead Levels in Lactating Cows Reared in Suburb of Sargodha: Transport of Lead into Milk, The Journal of Animal \& Plant Sciences, 22(4), 898-901.

Miranda, M., Lopez-Alonso, M., Castillo, C., Hermandez, J. and Benedito, J. L. (2005). Effects of moderate pollution on toxic and trace metals levels in calves from a polluted area of northern Spain. Environmental Instrumentation. 31, 543-548.

Nnaji, J. C., Uzairu, A, Harrison, G. F. S. And Balarabe, M.L. (2007) Evaluation of Cadmium, Chromium, Copper, Lead And Zinc Concentrations in the Fish Head/Viscera of Oreochromis Niloticus and Synodontis Schall of River Galma, Zaria, Nigeria, Ejeafche, 6 (10), 2420-2426

Needleman, H. (2004). "Lead poisoning". Annual review of medicine55: 209-222

Nwude D. O., Okoye, P. C. and Babayemi, J. O. (2010a). Blood Heavy Metals Levels in Cows at Slaughter at Awka Abattoir, Nigeria. International Journal of Diary Science. 5 (4) 264-270.

Ogabiela, E. E., Yebpella, G. G., Adesina, O. B., Udiba, U.U., Ade-Ajayi F. A., Magomya A.M., Hammuel, C., Gandu, I., Mmereole, U.J \& Abdulahi, M. (2011c). Assessment of Metals Levels in Cow Blood from Cow's Grazed around Zango, Zaria and Challawa Industrial Estate, Kano - Nigeria. Journal of Applied Environmental and Biological Sciences, 1(4), 69-73.

Ogundiran, M. B., Ogundele, D. T., Afolayan, P. G. and Osibanjo, O. (2012). Heavy Metals Levels in Forage Grasses, Leachate and Lactating Cows Reared around Lead Slag Dumpsites in Nigeria, Int. J. Environ. Res., 6(3), 695-702.

Ologe, K.O. (1971). Gully Development in the Zaria Area, Northern Nigeria (with particular reference to the Kubanni Basin). Unpublished Ph.D Thesis University of Liverpool.

Oluokun J. A., Fajimi, A. K., Adebayo, A. O. \& Ajayi, F. T. (2007). Lead and cadmium poisoning of goats raised in cement kiln dust polluted area. Journal of Food, Agriculture \& Environmen, 5 (1), 382 - 384 .

Staudinger K. C. \& Roth V. S. (1998). Occupational lead poisoning. Animal Farm Physician,57 (4),719-26, 731-2.

Sven H. (2000). Lead poisoning in a historical perspective. American Journal of Industrial Medicine, 38, 244-254.

The Sun (2015, May 26), 28 children die of Lead poisoning in Niger State, retrieved $30^{\text {th }}$ May 2015 from sunnewsonline.co

UNEP, (2007). Environmental pollution and impact to public health; implication of the dandora municipal dumping site in Nairobi, Kutoka Network, Kenya. Retrieved January 28, 2012 from www.kutokanet.com

Uzairu A., Harrison, G.F.S., Balarabe, M. L. \& Nnaji, J.C. (2009). Concentration Levels Of Trace Metals In Fish And Sediment From Kubanni River, Northern Nigeria. Bull. Chem. Soc. Ethiop. 23(1), 9-17.

WHO, (1984). Guidelines for drinking water quality. World Water. Geneva, Switzerland, WHO. 